Seyahat ve Otel İşletmeciliği Dergisi/

Journal of Travel and Hospitality Management

14 (2), 2017, 31-46.

Gönderim Tarihi:17.03.2016

Kabul Tarihi:08.08.2016

\title{
Sürdürülebilirlik Kapsamında Ekolojik Oteller: Narköy Ekolojik Otel ve Eğitim Merkezi
}

\author{
Ecological Hotels in Sustainability: Narköy Ecological Hotel and Training Center
}

Doç. Dr. Dilek DÖNMEZ POLAT

Çanakkale On Sekiz Mart Üniversitesi

Biga Uygulamalı Bilimler Yüksekokulu

E-posta: ddonmez@comu.edu.tr

Orcid Id: 0000-0002-3072-9340
Arş. Gör. Damla DEMIR HARPUTLUOĞLU

Çanakkale On Sekiz Mart Üniversitesi

Turizm Fakültesi

E-posta: deemir_damla@hotmail.com

Orcid Id:0000-0001-6609-9822

Öz

Günümüzde varlığını uzun süre korumak isteyen işletmelerin sürdürülebilirlik kriterlerini yerine getirmesi gerekmektedir. Sürdürülebilirlik kriterleri işletmelerin malzeme seçiminden yapım aşamasına ve işletme faaliyetlerinin yerine getirilmesi aşamasına kadar tüm süreçlerde dikkate alınmalıdır. Ekolojik oteller turizm sektöründe sürdürülebilirlik kriterlerinin yerine getirilmesinde önemli bir yere sahiptir. Sürdürülebilir turizm kapsamında ekolojik otellerin yerini, işlevlerini ve önemini incelemeyi amaçlayan bu çalışmada nitel yöntem uygulanmıştır. Ele alınan bu çalışma bir örnek olay incelemesidir. Bu bağlamda, turizmde yeni bir oluşum olan ekolojik otellere ilişkin bilgiler hakkında somut bir örnek olarak "Nar Köy Ekolojik Otel ve Eğitim Merkezi”ne ait faaliyetler değerlendirilmiştir. Veriler, yarı yapılandırılmış görüşme formu ile yüz yüze görüşme yöntemi, gözlem ve doküman incelemesi yardımıyla toparlanmıştır. Elde edilen bulgular ışığında ekolojik otel faaliyetlerinin sürdürülebilir turizmin tüm amaçlarını ve prensiplerini karşıladığı sonucuna varılmıştır. Bu bakımından sürdürülebilir turizm kapsamında ekolojik otellerin yeri ve önemi oldukça büyüktür.

Anahtar Kelimeler: Sürdürülebilir turizm, eko turizm, ekolojik oteller, narköy ekolojik otel ve eğitim merkezi.

\begin{abstract}
Today businesses that want to protect the long term existence is required to comply with the sustainability criteria. Sustainability criteria should be considered in all processes from material selection to construction and to fulfillment stage of business activities. Ecological hotels have an important place in the fulfillment of criteria for sustainability in the tourism sector. This study that aim to evaluate location, importance and functions of the ecological hotels as part of sustainable tourism, was conducted as a qualitative study. In this context, activities of "Narköy Ekolojik Otel ve Eğitim Merkezi" as a concrete example about information on ecological hotel that is a formation, are evaluated. Data were recovered with the help of observation, document analysis and face to face interviews with semi-structured interview form. In the light of the findings, it was concluded that ecological hotel activities meet all the objectives and principles of sustainable tourism. In this regard, place and importance of the ecological hotel is quite large within the scope of sustainable tourism.
\end{abstract}

Keywords: Sustainable tourism, ecotourism, ecological hotels, narköy ecological hotel and training center. 


\section{Giriş}

Turizm faaliyetlerinin kendine özgü doğası, hizmet kalitesi, turist sayısının artışı ile birlikte doğal ve kültürel kaynakların daha fazla kişi tarafından kullanılmasının getirdiği çevresel sonuçlar, çıkan sorunları çözmeye yönelik önlemler ve politikaların yapısı ciddi biçimde üzerinde durulması gereken konulardır (Erdoğan, 2003). Artan çevre sorunlarına çözüm olarak öne sürülen sürdürülebilirlik ve sürdürülebilir kalkınma kavramları, çevreye verilen zararın en alt düzeye indirilmesine yönelik uygulamaları ön plana çıkarmaktadır. Ciddi bir enerji tüketicisi olan turizm sektöründe temiz ve yenilenebilir enerji kaynaklarının kullanımının artması, sürdürülebilir kalkınma ve sürdürülebilir turizm hedeflerine ulaşılmasına olanak verecektir (Lim ve McAleer, 2005).

Herhangi bir turizm destinasyonundaki faaliyetlerin çevreye zarar vermesi diğer turizm destinasyonlarını da etkilemektedir. Kamu organları, işletmeler, turistik tüketiciler ve yerel halk da dâhil olmak üzere turizmde yer alan tüm tarafların çevresel sorumluluk yüklenmesi gerekliliği, doğal kaynakların tükenebilir yapıda olduğunun farkına varılması üzerine ortaya çıkmıştır (Cooper ve Wahab, 2001).

Turizmin sürdürülebilir olabilmesi için, taşıma kapasitesi ve ekosistemlerin kaldırabileceği limitler içinde yönetilmesi ve biyo-çeşitliliğin korunması gereklidir. Turizmin çok hızlı ve başarılı gelişimi doğal çevreye zarar verirken, doğal kaynakların tükenmesi turizmin en önemli varlığını ortadan kaldırmakta ve bölgenin çekiciliğini azaltmaktadır. Sürdürülebilir turizmde pazarlamanın temeli çevre ve kaliteye dayanmaktadır (Seyhan ve Yılmaz, 2010).

Günümüzde birçok otel, turizm ve çevre ilişkisinin ortaya çıkardığı sorunlara bağlı olarak çevreye verdikleri zararı en aza indirebilmek ve turizmden daha fazla pay alabilmek için çevre dostu uygulamalara geçmek zorunda kalmışlardır (Manaktola ve Jauhari, 2007; Dief ve Font, 2010). "Çevreye duyarı" davranan kuruluşların etkisiyle ve "çevre dostu" kavramının giderek önemsenmesiyle, eko otel tercih eden sorumlu turist sayısında artış gözlemlenmektedir. Yapılan araştırmalar, günlük hayatlarında çevre dostu davranışlar konusunda olumlu tutumları olan tüketicilerin, konaklama işletmelerinin çevre dostu yönetimlerini de olumlu karşıladığını göstermektedir. Bu bağlamda, tüketicilerin ekolojik otellerden hizmet satın alma eğilimlerinin yüksek olacağı, bu tarz otelleri başkalarına tavsiye edebilecekleri ve bunun için daha fazla maliyete katlanabilecekleri tespit edilmiştir (Han ve diğ., 2011). Bu durum ise ekolojik otellerin önemini her geçen gün artırmaktadır.

Bu çalışma sürdürülebilir turizm kapsamında ekolojik otellerin yerini, önemini ve işlevini ortaya koymak amacıyla gerçekleştirilmiştir. Bu bağlamda sürdürülebilir turizm ve ekolojik oteller hakkında literatür taraması yapıldıktan sonra örnek olarak ele alınan Nar Köy Ekolojik Otel ve Eğitim Merkezi ile yapılan görüşme, gözlem ve doküman inceleme gibi veri toplama teknikleriyle elde edilen veriler yorumlanarak sonuca varılmıştır.

\section{Sürdürülebilir Turizm}

İçinde bulunduğumuz dönem işletmelerin sadece mal ve hizmet üretimi ve satışı ile finansal başarı elde etmelerinin yeterli bulunmadığı, aynı zamanda çevreye ve insana duyarlı iyi birer işletme olmalarının beklendiği küresel bir dönüşüm sürecine şahitlik etmektedir. Sürdürülebilirlik kavramı da bu sürecin bir yansıması olarak son zamanlarda sektörlerin ve işletmelerin gündeminde sıklıkla yer almaktadır (Borsa 
İstanbul, 2014). Sürdürülebilirlik kavramını gündemine alan sektörlerden birisi de turizm sektörüdür.

Turizm dünyanın en geniş endüstrilerinden biri olarak gezegen üzerinde önemli bir toplumsal ve ekolojik etkiye sahiptir. Turizm endüstrisi yenilenemeyen kaynakların önemli bir kullanıcısı durumundadır. Sürekli bir turizm gelişmesi için gerekli ön koşullar tanımlandığında sürdürülebilir gelişme ilkeleri ile örtüştüğü görülür (Ceylan, 2001). Kalkınma ya da bölgesel gelişmede önemli bir alt sektör olarak nitelediğimiz turizm, çevre ve doğal kaynaklarla olan sıkı ilişkisi nedeniyle kalkınma ve çevre ilişkisinin uyumluluğa dönüştürülmesi gereğini ortaya koymaktadır. İşte bu noktada, çevre, ekonomi ve turizmi gittikçe artan bir önemle birbirinin parçası olarak görmek, çevre kalitesini sürdürmek, kalkınmayı eşitlemek temel hedeflerini içeren sürdürülebilir turizm kavramı ortaya çıkmaktadır (Beyhan ve Ünügür 2005).

Sürdürülebilir turizmin ilkeleri Dünya Turizm Örgütü (UNWTO-World Tourism Organisation) tarafından 1988 yılında belirlenmiş olup, sürdürülebilir turizm; "kültürel bütünlüğü, temel ekolojik süreçleri, biyolojik çeşitlilik ve yaşam destek sistemlerini korurken aynı zamanda ekonomik, sosyal ve estetik ihtiyaçları da sağlayabilecek şekilde tüm kaynakların yönetimi olarak öngörülmüştür" şeklinde tanımlanmıştır (UNWTO, 2009).

Kaynakların sürdürülebilir kullanımı ve çevre tahribinin önlenmesini amaçlayan sürdürülebilir turizmin özellikleri Akşit (2007:445)'e göre;

$>$ Doğa temelli olması

$>$ Biyoçeşitliliğin korunmasına katkıda bulunması

$>$ Yerel toplumların refahını desteklemesi

$>$ Olumsuz çevresel ve sosyo-kültürel etkilerin minimuma indirgenmesi için aktivitelerini hem turistler hem de yerel halkın sorumluluğunda düzenlemesi

$>$ Yenilenemez kaynakların minimum kullanımını gerektirmesi

> Yerel mülkiyetin ve yerel topluma dönük istihdam imkânlarının üretilmesini öngörmesi şeklinde sıralanmıştır.

Sürdürülebilir turizm; yöredeki insanların ve turistlerin intiyaçlarını gelecekteki fırsatları da koruyarak karşılama anlayışıdır (Avcıkurt, 1997:136). Bu kavram gün geçtikçe gelişerek turizme uygulanmış ve turizm planlaması, gelişimi ve işleyişinde, korunmuş bölgelerde turizm, otel işletmesi vb gibi alanlarla ilgili bir kavram haline gelmiştir (Garrod ve Fyall, 1998:203).

\section{Eko Turizm ve Ekolojik Oteller}

Öztürk (2005:140)'e göre; ekoturizm olgusu ilk olarak 1987 yılında Ceballas-Lascurian tarafından, "insanın olumsuz etkilerinin nispeten az olduğu alanlara manzara, bitki örtüsü ve hayvanların yanı sıra geçmişte ve günümüzde halen bulunan kültürel kaynak değerlerine hayranlık duymak, hoşlanmak ve özel bir çalışma yapmak için yapılan seyahatler" olarak tanımlanmıştır. Uluslararası Ekoturizm Derneği (TIES-The International Ecotourism Society) (1990)'nin tanımına göre ekoturizm; çevreyi koruyan ve yerel halkın refahını geliştiren, doğal alanlara yapılan sorumlu seyahattir. IUCN Uluslararası Doğayı Koruma Birliği (IUNC- International Union for Conservation of Nature) ise eko turizmi; "geçmiş ve gelecekteki kültürel özelliklerin her birine eşlik ederek düşük ziyaretçi etkisi ile korumayı geliştiren, yerel halkın aktif sosyo-ekonomik katılımına olanak tanıyan, doğadan zevk almak ve doğanın değerini anlamak amacıyla doğal alanda yapılan çevresel açıdan sorumlu seyahat" olarak tanımlamıştır (The Nature Conservancy 2009). 
UNWTO'ya göre eko turizmin amaçları (Özkan 2005);

- Turizmin doğal ve geleneksel çevreye verdiği tahribatın en alt düzeye indirilmesi,

- Turistlere ve yerel halka doğanın ve geleneksel sosyo-kültürel çevrenin korunmasına yönelik eğitim verilmesi,

- Turizmin yerel halkın intiyaçlarını karşılayan, yerel yönetim ve halkla işbirliği içinde gelişen sorumlu bir ticaret olarak özendirilmesinin sağlanması,

- Koruma kapsamındaki (doğal ve sosyo-kültürel) alanların yönetimi için kaynak ayrılması,

- Turizmin negatif etkisinin en alt düzeye indirilmesi amacıyla sosyo-kültürel ve doğal çevreye yönelik uzun vadeli takip ve değerlendirme programlarının desteklenmesi,

- Turizmin yerel halkın geçimine katkıda bulunmasını sağlayacak şekilde geliştirilmesinin temini,

- Turizmin gelişiminin yörenin sosyal ve çevresel kapasitesini artıracak şekilde gelişmesinin temini,

- Çevreyle uyumlu, doğal ve geleneksel sosyo-kültürel yaşamla iç içe geçen, yöresel bitki örtüsünü ve yaban hayatını koruyan turizmin alt yapı yatırımlarının gerçekleştirilmesidir.

Turizmin sürdürülebilirliğini sağlamak ve turizmin çekiciliğini arttırmak amacıyla günümüzde turizmin bir çeşidi olarak ortaya çıkan ekoturizm terimi 1983 yılında Hector Ceballos-Leascurain tarafından ortaya atılmış ve ekoturizm doğadan zevk alma ve doğanın kıymetini bilme şeklinde tanımlanmıştır. Ekoturizmin doğa temelli olması, kültürel olması ve kaynağın değerini anlama şeklinde üç temel öğeyi içerdiği belirtilmektedir (Erdoğan, 2003). Türkiye'de eko otel uygulaması ve tanımlaması Kültür ve Turizm Bakanlığı'nın "Yeşil Yıldız Sertifika Sistemi” ile başlamıştır. Türkiye'de çevre konusundaki duyarılıı̆ın artması ile birlikte dünyadaki uygulamalar ile birlikte söz konusu duyarlılık projesi başlamıştır. Bu kapsamda ilgili kanun (Turizm İşletmesi Belgeli Konaklama Tesislerine Çevreye Duyarlı Konaklama Tesisi Belgesi Verilmesine Dair 2008/3 no'lu Tebliğ) ile belirtilmiş olan kriterlere uyan konaklama tesisleri "Yeşil Yıldız" alabilmekte ve bu doğrultuda müşterilerine hizmet verebilmektedir. Türkiye'de özel bir ekolojik otel tanımlaması yapılmadığı için, ilgili bakanlığın özetlenmiş olan kriterlerini tamamlayan oteller ekolojik otel olarak sınıflandırılmaktadır (Başgöze ve Bayar, 2015:120). Turizm Databank'ın derlediği bilgilere göre Türkiye'de Kültür ve Turizm Bakanlığı'ndan belgeli Yeşil Yıldızı (Çevreye Duyarlı) otel sayısı Haziran 2016 turizm verilerine göre 327'e ulaşmıştır. Var olan illere göre dağılıma bakıldığında Antalya turizmi ilk sırayı almakta ve toplamda Yeşil Yıldız belgesini 110'dan 172'ye çıkaran Antalya, belgelerin de \% 52'sine sahip olarak öne çıkmaktadır (Turizm Dosyası, 2016).

Konaklama, turizmin olmazsa olmaz unsurlarından biridir. Turizmde sürdürülebilirlik anlayışının gelişmesiyle birlikte "ekolojik otel" kavramı da giderek önem kazanmaktadır. Ekolojik oteller literatürde; verimli enerji, su, atık yönetimleri ile doğal kaynakları doğaya saygılı biçimde kullanarak kaliteli hizmet üreten oteller olarak tanımlamaktadır (Cooper 1998:113). Güneş (2011:48) ise ekolojik otelleri "su ve enerji tasarrufu sağlayan, katı atıkları azaltan, geri dönüşüm ve yeniden kullanım programları uygulayan, sürdürülebilir çevre düzenlemeleri ve ekonomik çözümler geliştiren oteller" olarak tanımlamıştır.

Ekolojik konaklama yapılarının biçimleniş ilkelerine baktığımızda; ekolojik malzeme kullanıldığı, ömrünü doldurduğu zaman doğada atık teşkil etmeyecek küçük yapılar olarak tasarlandıkları, mekânda enerjinin korunması için alınan tedbirler, ISı 
yalıtımı, suyun arıtılıp başka yerlerde kullanılması, güneş enerjisinden faydalanan sistemler, balmumu gibi doğal malzemelerle aydınlatılan mekanlar, insan enerjisinin elektriğe dönüştürülüp yapı içinde kullanan yaklaşımlar, yapılan aktivitelerle ekoloji bilincinin desteklendiği görülmektedir (Pehlivanoğlu, 2010).

\section{Araştırmanın Yöntemi}

\subsection{Araştırmanın Kapsamı ve Amacı}

Bu çalışmanın temel amacı, Türkiye'de ekolojik otel olarak faaliyet gösteren otelleri daha yakından ele alma ve tanıtma ihtiyacıyla ekolojik bir konaklama işletmesinin faaliyetlerini derinlemesine incelemektir. Bu amaç doğrultusunda çalışmada araştırma yöntemi olarak nitel araştırma yöntemi kullanılmıştır. Çalışmanın alt amaçları ise; örnek konaklama işletmesinin enerji verimliliği, tasarım, geri dönüşüm ve atıklar gibi ekolojik faaliyetlerini inceleyerek bu faaliyetlerin sağlayabileceği avantajları ve dezavantajları göstermek ve bu uygulamaların nasıl olabileceğine dair bir örnek sunmaktır.

Çevresel sorunların gündeme gelmesiyle birlikte birçok işletme çevreye duyarlı faaliyetlerde bulunmakta ya da bunun hazırlığını yapmaktadır. Hatta çoğu kriterleri taşımamalarına rağmen kendilerini ekolojik otel olarak adlandırmaktadır. Ancak Nar Köy Ekolojik Otel ve Eğitim Merkezi ile birebir aynı niteliklere sahip başka bir otel bulunmamaktadır. Bu sebeple karşılaştırmalı analiz yapılamamıştır.

Ele alınan bu çalışmada nitel araştırma yöntemi kullanılmıştır. Nitel araştırma yönteminin kullanılmasının sebebi; doğal ortama duyarlı olması, araştırmacıya katılımcı bir rol yüklemesi, bütüncül yaklaşım yapabilme, algıların ortaya konması, araştırma deseninde esnekliktir (Yıldııım ve Şimşek, 2006). Nitel araştırmalarda her zaman ilgili evreni temsil edecek örneklemi belirlemek mümkün olmamakta ve nicel araştırma örneklemine oranla daha küçük örneklem olduğu için bulguların genellenmesi güç olmaktadır (Miles ve Huberman, 1995:27; Yin, 2011:66). Bu nedenle nitel araştırmalardaki örneklem seçiminde nicelik temsilinden ve örneklemin temsil gücüne bakılmasından daha çok araştırma konusuyla ilgisine bakılır. Buradaki amaç kasıtı olarak seçilen örneklemden konu hakkında daha fazla bilgi toplanabilmesidir (İslamoğlu ve Alnıaçık, 2013:208). Bu araştırmanın temel problemi, sürdürülebilirlik kapsamında ekolojik otellerin yeri, işlevi ve önemini belirleyebilmektir. Otelin bu alandaki çalışmaları araştırmanın konusu olmuştur.

Örnek Durum/Olay çalışması; güncel bir olguyu kendi gerçek yaşam çerçevesi içinde çalışan, olgu ve içinde bulunduğu içerik arasındaki sınırların kesin hatlarıyla belirgin olmadığı ve birden fazla kanıt veya veri kaynağının mevcut olduğu durumlarda kullanılan görgül bir araştırma yöntemidir (Yıldırım ve Şimşek, 2013:314). Araştırmaya katılacak ekolojik oteli belirlemek için amaçlı örnekleme yöntemlerinden ölçüt örnekleme yöntemi kullanılmıştır. Bu yöntemdeki anlayış önceden belirlenmiş bir dizi ölçütü karşılayan bütün durumların çalışılmasıdır. Bu ölçütler araştırmacı tarafından oluşturulabileceği gibi daha önceden hazırlanmış bir ölçüt listesi kullanılabilir (Yıldırım ve Şimşek, 2006). Örnek olay olarak incelenecek otel seçiminde ise kriter olarak, ekolojik otel olmanın gereğini tam anlamıyla yerine getirebilme ve ulaşılabilirlik ölçütleri konulmuştur.

Bu çalışmada gözlem, görüşme, mevcut dokümanları ve arşiv kayıtlarını inceleme gibi birden fazla veri toplama yöntemi kullanılarak veri çeşitlemesine gidilmiştir. Görüşme öncesinde araştırmacı tarafından sürdürülebilir turizmin boyutları göz önüne alınarak yarı yapılandırımış görüşme formu düzenlenmiştir. Düzenlenen 
görüşme formu bu alandaki uzmanlarca incelenmiş ve son halini almıştır. Otel Müdürü ile 29.12.2015 tarihinde bizzat araştırmacı tarafından yüz yüze görüşme gerçekleştirilmiştir. Görüşmede katılımcıya işletme hakkında genel bilgi almak için 3 soru sorulmuştur. Sonrasında ise yapılan literatür taraması sonucunda oluşturulan sürdürülebilir turizmin çevresel boyutu ile ilgili 6 soru, ekonomik boyut ile ilgili 3 soru ve son olarak sosyal boyut ile ilgili 3 soru sorularak toplamda 18 soru cevaplanması istenmiştir. Araştırma sürecinde mülakat sorularının açık uçlu olmasına özen gösterilmiştir Açık uçlu soruların sorulması ile araştırma soruları daha ayrıntılı hale gelmiştir. Otel yöneticisi ile yapılan görüşmede sorulan sürdürülebilir turizmin boyutlarına ilişkin açık uçlu sorular aşağıdaki tabloda verilmiştir.

\section{Tablo 1: Görüşme Soruları}

\begin{tabular}{|l|}
\multicolumn{1}{|c|}{ Çevresel Boyutla İlgili Sorular } \\
\hline 1. İşletmenizin çevre politikası nedir? \\
\hline 2. Atık yönetimi uygulamalarınızdan bahseder misiniz? \\
\hline 3. İşletme içindeki ekolojik faaliyetleriniz nelerdir? \\
\hline 4. İşletmenizin sahip olduğu kalite belgeleri var mı? Varsa açıklar mısınız? \\
\hline 5. Otelinizin inşaatı ve tasarımı sırasında danışmanlık aldınız mı? \\
\hline 6. Otelinizin yapı malzemesi olarak seçtiğiniz ürünlerin çevresellik boyutu nasıl? \\
\hline \multicolumn{1}{c|}{ Ekonomik Boyut ile Illgili Sorular } \\
\hline 7. Çalışan profiliniz nedir? Çalışanlarınızın yüzde kaçı yerel halktan seçilmektedir? \\
\hline 8. Tedarikçi profilinizden bahseder misiniz? Yerel halkla çalışma oranınız nedir? \\
\hline 9. İşletme olarak yerel halka istihdam dışında ne gibi katkılarınız var? \\
\hline \multicolumn{1}{c|}{ Sosyal Boyutu ile İlgili Sorular } \\
\hline $\begin{array}{l}\text { 10. İşletmenizin yerel kültürü koruma, gelecek nesillere aktarma hususunda ne gibi } \\
\text { işlevleri olabilir? }\end{array}$ \\
\hline 11. Çalışanlara çevresel faaliyetler hakkında verilen eğitimlerden söz edebilir misiniz? \\
\hline 12. Gelen misafirlere bölge ve kültür hakkında nasıl bilgilendirme yapıyorsunuz? \\
\hline
\end{tabular}

\subsection{Araştırmanın Geçerlilik ve Güvenirliği}

Araştırmanın iç geçerliliği için "üye denetimi” yöntemi kullanılmıştır. Üye denetimi, hakkında araştırma yapılan ve verileri sağlayan kişilerce gerçekleştirilen denetim demektir. Bir görüşmenin yazılı hali, kaydın doğru olduğunu denetlemesi için, raporlaştırmaya geçmeden önce görüşmeciye sunulur (Punch, 2005: 245). Bu doğrultuda ses kayıt cihazlarına kaydedilen görüşmeler çözülerek yazılı metin haline getirilmiş raporlaştırılmadan önce görüşmecilere sunulmuştur. Otel yöneticisinin onayı alındıktan sonra veriler araştırmada kullanılmıştır. Bunun yanında yine iç geçerliliğin sağlanabilmesi adına uzman incelemesi ve çeşitleme stratejileri kullanılmıştır. Dış geçerliliği sağlamak amacıyla ise, ayrıntılı betimleme ve amaçlı örnekleme stratejileri kullanılmıştır. Dış güvenirliği sağlamak amacıyla ise teyit incelemesi yöntemine başvurulmuştur.

\subsection{Veri Analiz Tekniği}

Görüşme formundan elde edilen verilerin analizinde betimsel analiz tekniği kullanıımıştır. Betimleme aşamasında araştırmada toplanan verilerin araştırmanın amacına ilişkin olarak neleri söylediği ya da hangi sonuçları ortaya koyduğu ön plana çıkmaktadır. Veriler, görüşme sürecinde kullanılan sorular ya da boyutlar dikkate alınarak sunulur (Yıldırım ve Şimşek, 2013). 


\section{Bulgular}

Sürdürülebilir turizm kapsamında ekolojik otellerin önemini, işlevini ve yerini bulmak amacıyla bu bölümde çeşitli veri toplama teknikleri ile elde edilen bulgular, sürdürülebilir turizmin üç boyutu olan ekonomik, çevresel ve sosyal boyutları altında incelenecektir.

Ekonomik boyutunu incelemek için, çalışan profili, çalışanlarınızın yüzde kaçı yerel halktan, tedarikçi profili ve yerel halkla çalışma oranı ve son olarak, yerel halka istihdam dışında ne gibi katkılar sağlanıyor gibi soruların cevapları incelenmiştir. Çevresel boyutta ise, işletmenin çevre politikası, işletme içindeki ekolojik faaliyetler, işletmenin sahip olduğu kalite belgeleri ve ödüller, otelin tasarım ve inşaat aşaması, otelin yapı malzemesi olarak seçilen ürünlerin çevresellik boyutu, sunulan yiyecek içecek hizmetlerinde kullanılan malzemelerin doğallık durumu gibi soruların cevapları incelenmiştir. Son boyut olan sosyal boyutta ise, yerel kültürü koruma, gelecek nesillere aktarma hususunda neler yapıldığı, işletmede kullanılan ürünlerin yerellik boyutu ve oranı, çalışanlara çevresel faaliyetler hakkında verilen eğitimler, gelen misafirleri bölge ve kültür hakkında bilgilendirme gibi soruların cevapları incelenmiştir. Sürdürülebilir turizmin boyutları altında incelemeye başlamadan önce Narköy Ekolojik Otel ve Eğitim Merkezi'ni genel olarak tanımanın faydası olacaktır.

\subsection{Narköy Ekolojik Otel ve Eğitim Merkezi}

Narköy, Nar Eğitim ve Danışmanlık Merkezi'nin eğitim odaklı sürdürülebilir turizm merkezi ve organik tarım çiftliğidir. Narköy, eğitim odaklı bir merkez olarak çağdaş bir çiftlik ve otel mantığıyla yaşamakta ve hizmet vermektedir. 14 oda, aile ve grup konaklama üniteleri, yörük çadırı, organik çiftlik yemeklerinin pişirildiği restoran, açık ve kapalı derslikler, organik tarım çiftliği, muhteşem bir orman ve doğanın sürprizlerini sunan Narköy'de, çeşitli eğitim, aktivite ve atölye çalışmaları mevcuttur. "Küresel düşün, yöresel hareket et" felsefesiyle hayat bulan mimarisi, doğadan öğrenerek, yararlanarak ve ona katkı sağlayarak işlemek üzere tasarlanmıştır. Katılımcı Narköy'ü genel olarak açıklarken şu ifadeleri kullanmıştır: "Nar Anne düşü olmayanın işi olmaz der. Onun düşü burası. Kızının yazdığı bir mektupla başlıyor her şey. Sonra 2002'de Nar Eğitim ve Danışmanlık Şirketi'ni kuruyor. Üçayaklı bir şirketiz, Bir ayağımız eğitim danışmanlık, bir ayağımız çiftlik, bir ayağımız da otel. Üçü de sağlam basıyor şuan yere."

Narköy'ü, bölgeyi ve Narköy'ün kuruluş aşamasını açıklar mısınız sorusun otel yöneticisinin verdiği cevap aşağıda detaylı bir şekilde açıklamıştır.

"Narköy 3 yıldızlı bir otel. İzmit ilinin Kandıra daha doğrusu Kerpe bölgesinde faaliyet göstermektedir. Yerli turizme açık bir lokasyon. Yatırımlar çok düşük. Konaklamalar genelde pansiyon tarzında Bir tane büyük otel var. Iki buçuk aylık bir yaz sezonu var. Bu iki buçuk aydan sonra da hiç bir in cin kalmıyor bu civarda. Bir çok misafirin bizi tercih etme sebebi burada gelip sağlılık besinlerle doğal yollarla beslenip huzurlu bir iki gün geçirip, tazelenip detokslanıp şehre geri dönmek tekrardan. Narköy'ün kuruluşu 2007 senesinde çiftlikle hayata geçiyor. Toplamda 120 dönüme yakın bir arazi satın alınması yapılmadan evvel toprak analizi yapılarak toprağın organik tarıma elverişli olup olmadığı test ediliyor Toprakta yaklaşık 15-20 sene boyunca hiç bir ekim dikim faaliyeti yapılmadığı için toprak tamamen bakir, yani temiz. Bunun üzerine, Kuşçu ailesi Nar Annenin önderliğinde buranın satın almasını gerçekleştiriyorlar. Bu 120 dönümün yaklaşık yarısına yakın bir alanda şuanda organik tarımla uğraşıyoruz. Arazinin yapısı itibarı ile kışın traktör veya araç giremediği için belli 
bölümden sonrasını meyvelik yaptık, fidanlık yaptık. 2000 küsur fidanımız var şuanda 2-3 sene içerisinde de çok ciddi miktarda meyve üretimine geçeceğiz. Burada yetişebilecek her türlü meyve ağacından diktik. Onun dışında burada yapılan tarım tamamen mevsiminde hangi ürün varsa onun üzerine yetiştiriliyor ve yetiştirilen ürünlerin tamamıla otel misafirlerine sunulduğu bir tesis. Otelin kuruluşu 2013 senesinde. 2 senelik bir inşaat süreci var yaklaşık. Bütçe 3-3.5 milyon lira iken 8 milyon liraya çıkıyor. Bunun sebebi de binaların ekolojik olması, bununla ilgili yapılan yatırım."

"Toplamda 61 kişiye kadar misafir ağırlayabiliyoruz. Artı çiftlik tarafında bir tane yörük çadırımız var keçi kılından yapılmış bildiğimiz yörük çadırı. Orada da 16 misafir ağırlayabiliyoruz. Konaklamalarımız tam pansiyon şeklinde, artı saatlik rehberle doğa yürüyüşü, ekim dikim, süt sağımı sunuyoruz ve mevsimine göre at bindirebiliyoruz misafirlere ücretimiz içinde".

\section{Resim 1: Resepsiyonda Asılı Hafta Sonu Etkinlik Panosu}

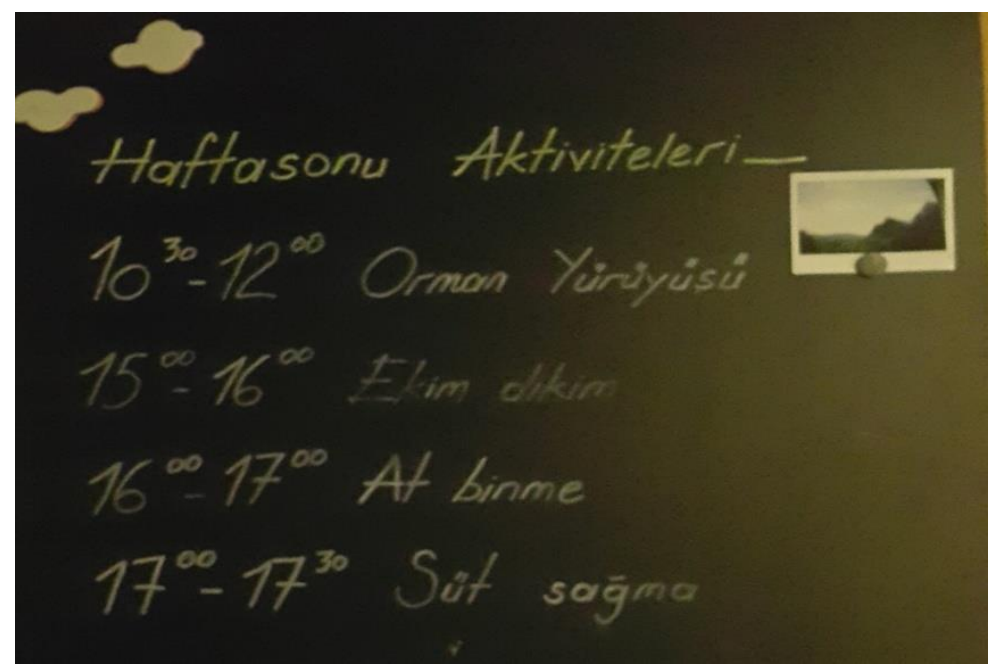

"Bizim amacımız para kazanmak değil. Vizyonumuzu insanlarla paylaşmak. Vizyonumuzu anlayacak insanların otelimize gelmesi, bu insanlara kendimizi ifade edip onların bizi anlamasını sağlamak."

\subsection{Sürdürülebilir turizmin çevresel boyutuyla incelenirse;}

Çevresel boyutu ele almak için öncelikle Narköy'ün çevre politikası araştırılmıştır. Narköy işletme politikası, doğaya en az zararla en büyük fayda sağlamak için çalışmaktır. Bu amaç doğrultusunda yapılan faaliyetleri sorduğumuzda ise katılımcının verdiği cevap aşağıda detaylı bir şekilde belirtilmiştir.

\section{Atık politikası;}

"Birincisi bizim hiçbir atığımız çıkmaz. Yemeklerimiz ortaya paylaşım usulü gelir. Bütün misafirleri beraber oturttururuz. Misafir kendi çatalını bıçağını yemeğe dokundurmadığı için artan yemekler hiçbir zaman çöpe atılmaz. En kötüsü bizim personel yemeğimiz olur. Son olarak da, tavuklarımıza gidiyor, köpeklerimize gidiyor, yal oluyor. Kızgın kızartılmış yağlar iki kullanımdan sonra bizde kullanılmaz. Endüstriyel yağ asla yoktur. Yağımız da organiktir. O kullanılan yağlar da daha sonra köpeklerin yalına gider. Bizde atık ne çıkar derseniz, bizde şudur; plastiktir, cam şişedir. Bunlar da ayrıştırılır özel çöp 
konteynırı belediyeden istenir. Ayrıca atık çıkmaması adına, şimdi her otelde ufak porsiyonlanmış şampuanlar, sabunlar vardır. Bizim şampuan ve sabunlarımız organik. Öyle olduğu için onları 5-10 litrelik kovalarda alıyoruz. Lavabo ve banyolarda dispanser içine konulmuş bir şekilde bulunurlar bu yüzden. Tasarruf etmek açısından. Bunun yanında odalarda kullanılan birçok ürün inşaatta kullanılıp artık olarak çıkan malzemeler. Otelin bütün inşaatında kullanılan malzemeler geri dönüşümlü malzemeler. Hiçbiri çözülmeyip doğaya zarar veren malzeme değil. Girdiğiniz resepsiyon ünitesi vardı ya o ne biliyor musunuz? Buradaki işçilerin inşaat sırasında kaldığı konteyner. Konteyner resepsiyon yapıldı. Dışarıda kırmızı saksılarımız var onlar inşaatların kalıp tahtalarıydı saksı yapıldı ondan. Odalarda yatak başuçları, masalar onlar hep malzemeleri inşaattan kalan malzemeler. Kullanılabilir hale getirildiler. Ekolojinin başı zaten doğaya zarar vermeyen, tekrar doğaya dönüştürülebilir ürünler kullanmak, burada her şey o şekilde."

\section{Su tasarrufu ve verimliliği;}

"Öncelikle bütün lavabo ve musluk bataryalarımız ve sifonlarımız hep tasarruf sistemine uygundur. Lavabo ve duşlardaki bir dakikada maksimum 6 litre su harcar. Hava karışımı karıştırarak su çok gibi gözükür ve bu şekilde tasarruf sağlanır. Sifonlarımız 6 litre ve altındadır mutlaka ve kullanılan gri suların hepsi geçen ay devreye giren biopart diye bir arıtma sisteminden geçiyor. Bunlar tekrardan toplanıp arıtılıp, bakteriyle arıttığımız için yine verimli bir yağmur suyu kalitesinde bahçe sulamada kullanılır. Biopart bizde yeni hayat geçti, yerli bir kuruluş. Tamamen kendi içindeki membaında bakteri üretiyor önce sistem, bakteri üretildikten sonra kirli gri suyu içeri atıp o bakteriler yardımıyla arıtıp, lezzetlendirip, değerlendirip tekrar toprağa verebiliyoruz o suları. Böylece yağmur suyuna yakın kalitede bir sulama sağlayabiliyoruz. Eskiden bu sistem yokken iki günde bir vidanjör gelip yaklaşık 8 ton atık çekerdi bizden. Şimdi o sekiz ton atığı kullanıp bahçeleri sulayabiliyoruz. Artı binalarımız yapılırken yine, özel çatı planaj sistemleri sayesinde yağmur suyu toplama sistemi yapıldı ve 40 tonluk bir depoya sahip olduk. Orası dolduğunda ve kullanma suyumuzdan da artığı zaman aşağıda bir ördek havuzumuz var oraya su basıyoruz. Dediğim gibi sulamada önceliğimiz yağmur suyunu kullanmak, sonra olmadı bioparttan gelen su, son çare şebeke suyudur ama bu sene ona gerek olacağını düşünmüyorum."

\section{Enerji verimliliği ve tasarrufu;}

"Enerji olarak, ısınma olarak şöyle; binalar yapılırken rüzgar ve güneş ışınlarının altı aylık güneş ışınları analizleri yapıldı. Binaların açıları hep birbirinden farklıdır. Bundaki amaç şuydu; yazın klima kullanmadan karbon emilimini minimize ederek nasıl iklimlendirebiliriz. Şöyle, iki camı karşılıklı açtığınız zaman camlar tavana kadardır, perdeleriniz kapalıysa, klimaya ihtiyaç duymadan odanızın sıcaklığı 21-22 derecede kalır. Kışın ise tam tersi, minimum ısıtıcıyla, elektrik harcayarak, camları kapalı, pencereniz açık bırakırsanız güneş ısısını içeri aldığı zaman oda sıcaklığı 21 derece civarı olur. Yazın çok yandım, dayanamıyorum dediğiniz zaman, pervanemiz vardır tavanda onu açabilirsiniz. Kışın ise duvarlar termostat ısı kontrollüdür. Onlarla ısınabiliyorsunuz. 3 tane binamızın altında makine dairesi olduğu için mecburen beton arma yapıldı Bu binaların ısıtması da yerden zeminden Isıtma, fakat ısıtmada kullanılan kazanlarımız pelet kazanları. Pelet, yaklaşık $5 \mathrm{~cm}$ boyunda sıkıştırılmış eski ağaç tozu. Onlar kapsül haline getiriliyor. Bu peletin en büyük avantajı doğaya en az karbonmonoksit ve zehir bırakan ürün. Böyle olduğu için buradan çıkan atığımız da minimumda ve yerden ısıtmayla sağlıyoruz. Odaların hepsinde yine termostat ayarları var. Güneş enerjisi ile bütün otelin sıcak su ihtiyacını karşılıyoruz. Ama güneş ışınlarının yetmediği durumlarda kendi elektrikle çalışan kazanlarımız var artı pelet 
kazanımız aynı zamanda bu 3 binanın mutfak da dahil sıcak suyunu karşılıyor. Ama yazın 4-5 ay boyunca sadece güneş enerjisi ile sıcak su ihtiyacı karşılanabiliyor. Şimdi yeni bir projemiz de var. Bütün tesisi otelin çevresindeki çiftliği besleyecek fotovoltaik panellerle elektrik üretimi projesi. Şuan onu da fiyatlandırıyoruz. Çok ciddi bir yatırım olacak."

Çevre politikasıyla ilgili olarak yukarıda belirtilenlere ek olarak otelde çamaşır deterjanı, bulaşık deterjanı ve sabunlar da organiktir. Bununla alakalı olarak ise katılımcı şunları aktarmıştır:

"Bütün kullandığımız deterjanlar turmepa'dır. Turmepa marine deterjanıdır. Atık bırakmayan, zararsız deterjanlardır. Onları kullanıyoruz. Bütün çamaşır, bulaşık makinelerimizde onlardan kullanıyoruz. Yazın veya güneşin olduğu bir anda asla kurutma makinesi kullanılmaz. Direk rüzgar ve güneş koksun diye güneşe sereriz çamaşırlarımızı."

Bunlara ek olarak işletmede ilaçlama da dahi kimyasal kullanılmamaktadır. Bunu örneklendirmek amacıyla sorulan soruya katılımcı aşağıdaki cevabı vermiştir.

"Sinekler hala ortada soğuktan kaçmak için müdahale edemiyoruz. Çünkü hiç bir kimyasal kullanamıyoruz. Karınca basınca sirkeli suyla siliyoruz. Mutfağı ilaçlamıyoruz bu yüzden kedilerimiz var. Bütün mücadelemiz doğal yollardan. Çiftlikte mesela seramızı böcek basıyor hemen kümes kuruyoruz oraya. Yirmi tane tavuk timi kuruyoruz. Tavukların başına da köpek koyuyoruz. Ürünün yarısını tavuklar yiyor ama iş yapmak için para kazanmaları lazım karınlarını doyurmaları lazım. En azından bitkiye böceğe yedirmektense tavuğumuza yediriyoruz, onu besliyoruz. Yumurtamız kaliteli oluyor ve böylece de böcekten kurtuluyoruz. Tıkalı lavobalarımızı ilk müdahalemiz limon tozu ve karbonattır. Bunun işe yaramadığı durumlarda ise kola kullanıyoruz."

Yine çevresel boyutu incelemek için işletmenin yapmış olduğu ekolojik faaliyetler sorulmuş ve ele alınmıştır. Gözlem ve görüşme sonucunda elde edilen bilgilere göre, Narköy'de konaklamanın yanı sıra organik tarımla uğraşılmaktadır ve çiftlik de mevcuttur.

\section{Resim 2: Çiftlik ve Organik Tarım Örnek Resimleri}

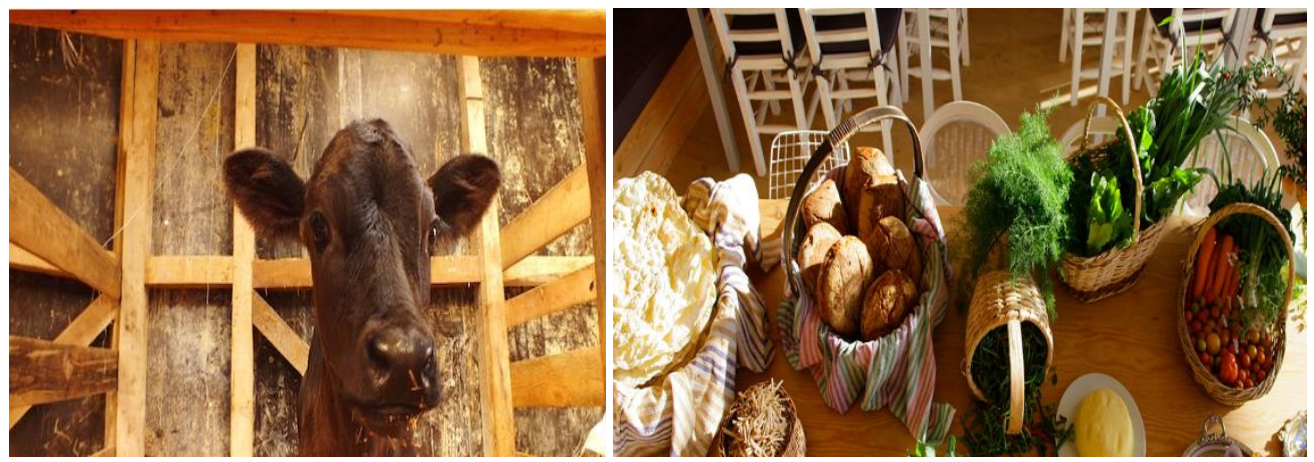

Bu konuyu ise katıımcı detaylı bir şekilde aşağıdaki gibi açıklamıştır.

"Bizim burada yaptığımız her şey doğaya en az müdahale ile yaptığımız işler. Yaklaşık 60 tane küçükbaş hayvanımız var teke, keçi gibi. 3 tane atımız var, bir tane eşeğimiz, yaklaşık 10-12 tane de büyük baş hayvanımız var buna ek olarak yaklaşık 200 tane tavuğumuz var, ördeklerimiz var. Bütün bunların gübrelerini kullanıyoruz hatta 
güvercin aldık onların gübreleri çok değerlidir onları da kullanıyoruz. Kendi kendimize yetebiliyoruz. Biz şu an kapılarımızı kapatsak, 200-250 kişiye kadar alıp aç kalmadan yaşayabiliriz."

"Ekolojik otel yönetimi, işletmesi, prensipleri zor ama yapılabilir ama organik tarım dünyanın en zor şeyidir. Şimdi burada mısır ekiyoruz, organik tohumlarımız var. Bizim en büyük hazinemiz 1200 tonluk tohum bankamızın olması. Türkiye'de mısır tohumları hep GDO'lu. Bizim tohumlarımız yerli mısırdır. Bunlar yıllar boyunca Nar Anne'nin (otelin kurucusu) yönetiminde toplanmıştır ve şu anda da hibe ve takas yoluyla artarak çoğalmaktadır. Artı, biz kendi ürettiğimiz ürünlerin mutlaka tohumlarını her son üründe topluyoruz. Eskiden nasıl bir köy hayatı yaşanıyorsa bizde öyleyiz. Temmuzun on beşi domatesimiz başlar eylül sonu ekim başı gibi domatesimiz biter. Ama napıyoruz hasatımızı püre yapıyoruz salça yapıyoruz, kışın kullanmaya çalışıyoruz. Yaptığımız püreden menemenimizi yapıyoruz ama her şey mevsiminde ve tadında yetişir. Hiçbir zaman onun dışına çıkmıyoruz. Şimdi sera çalışmalarımız var serayla ilgili üretime başladık çilek üretimine başladık. Kendi balımız var. Yaklaşık 50 tane kovanımız var. Onu da arılarla şirket kurduk ortak. Balın yarısını alırız, yarısını da onlara bırakıyoruz mutlaka. Çünkü kışın onunla besleniyorlar. Yoksa sahtekârlık yapıp yanlarına glikoz şekeri bırakırsak onu yerler. 50 kovandan biz 25 kilo bal alıyoruz senede."

Çevresel boyutla ilgili olarak yapılan ekolojik faaliyetlere ilişkin işletmenin sahip olduğu kalite belgeleri ve ödüllere bakıldığında ürünlerin organik olduğuna dair 'Organik Tarım Müteşebbis Sertifikası' mevcuttur. Bunu yanında işletme geçtiğimiz günlerde yeşil yıldız almaya hak kazanmıştır. Bu konu ile ilgili olarak ise katılımcı şunları aktarmaktadır.

"Yeşil yıldız aldık geçtiğimiz günlerde. Geçen ay denetimimiz yapıldı. Normalde üç yıldızlı bir tesisin yeşil yıldız alması için 170 puana ihtiyacı var. Biz bu halimizle 310 puan aldık. Beş yıldızı bir tesisin beş yıldızı haliyle alması geren puanı biz üç yıldızlı bir otel olarak aldık. Dün de imzadan çıktı onayımız. Herhalde 10-15 güne kadar bize gelecek yeşil yıldız plaketimizi resepsiyona asabileceğiz."

Çevresel boyutla ilgili olarak bir başka araştırma konusu ise, otelin tasarım ve inşaat aşamasında danışmanlık alınması ve otelin yapı malzemesi olarak seçilen ürünlerin çevresellik boyutudur. Bu konu ile ilgili olarak ise aktarılanlar aşağıda belirtilmiştir.

"Bu otelin mimarı zaten ekolojik oteller üzerine çalışan bir mimar. Nar Anne'nin kızı da mimar. Bu insanlar zaten hep ekolojik mimarı üzerine eğitim almış kişiler. Zaten Nar Anne toprak ve toprak ana konusunda vizyonu ve temel prensipleri ortaya koyan kişi o. O yüzden danışmanlığı zaten biz veriyoruz. Yeşil yıldızın kriterlerini bile bize bakarak yazabildiler. O kadar yani. Otel inşaatının yapılacağı bu bölgede tek bir ağaç bile kesilmedi. Üstteki verimli $50 \mathrm{~cm}$ kalınlığındaki toprak özellikle alınarak bir yerde saklandı inşaat bittikten sonra tekrar otelin etrafına serpildi ki verimli toprağı kaybetmeyelim diye. Otel binalarımızın konstrüksiyonu şuan içinde bulunduğumuz restoran gibi tamamen ahşap konstrüksiyondur. Toprağa kazık sistemi vardır temeli yoktur. Otel blokları çelik konstrüksiyondur. Toprakta temel yoktur, yine kazık sistemidir. Amaç nedir, ekolojik hayatı öldürmeden, yarın öbür gün biz Narköy'den vazgeçtik diyelim, binalarımızı kaldırdık altı ay içerisinde toprak tekrardan nefes aldığı anda, güneş gördüğü anda ekolojik hayat devam edecektir. O yüzden amacımız toprağa dokunmadan bu işi yapmak." 
Yukarıdaki bilgiler ve yapılan gözlemler neticesinde Narköy'de yapılan tüm faaliyetlerin öncelikli olarak çevre düşünülerek yapıldığını söylemek mümkündür. Bu da aslında ekolojik otelin en önemli prensiplerinden biridir.

\subsection{Sürdürülebilir turizmin ekonomik boyutuyla incelenirse;}

Yapılan faaliyetleri sürdürülebilir turizmin ekonomik boyutuyla irdelemek için öncelikle çalışan profili sorgulanmıştır. Bunun sonucunda ise çalışan yirmi personelin otel yöneticisi ve profesyonel aşçısı hariç hepsinin yerel halktan seçildiği öğrenilmiştir. Yine ekonomik boyutla alakalı olarak tedarikçi profili incelendiğinde ise işletmenin kendi kendine neredeyse yeten bir sistem içerisinde olduğu ve tedarikçi sayısının çok kısıtlı olduğu gözlemlenmiştir. Bu durumu katılımcı "Tedarikçimiz yok gibi bir şey. Kendimiz sadece dışarıdan temizlik malzemeleri onun dışında pek dışarıdan aldığımız bir şey yok. Etimizi bile kendimiz sağlıyoruz." olarak belirmiştir. Son olarak ise, işletmenin yerel halka istihdam dışında ne gibi katkıları olduğu sorulduğunda katılımcı burumu aşağıdaki gibi belirtmiştir.

"En büyük katkısı, bütün çalışanlarımız organik tarıma yönelttik. Hepsinin kendi toprakları var çalışanlarımızın ve şuan kendi bahçelerine bizim tohumlarımızla, aynı prensiple ürün yetiştiriyorlar. Bizim örneğin kıvırcı̆̆ımız yetmediğinde çalışanlarımızın birinin bahçesinden ürün alabiliyoruz ve bu şekilde hem ona maddi destek oluyor, hem temiz doğru ürün almış oluyoruz. Bu arkadaşlarımızın da bilinçlenmesiyle onların komşusu da bilinçleniyor. Bu bir zincir gibi ve taşı suya attığınızda suyun dalga dalga büyümesi gibi. Var oluşumuzla beraber "Kandıra ve Kerpe'ye çok büyük bir değer kattığımızı düşünüyoruz."

Yukarıda belirtilen bilgiler ışığında ekolojik otellerin yapmış olduğu ekonomik faaliyetlerin sürdürülebilir turizmin amaçlarından olan yerel mülkiyetin ve yerel topluma dönük istihdam imkanlarının üretilmesini öngörmesi ve yerel toplumların refahını desteklemesi hususlarının birebir örtüştüğü gözlenmektedir.

\subsection{Sürdürülebilir turizmin sosyal boyutuyla incelenirse;}

Örnek olarak ele alınan Narköy'de yapılan faaliyetleri sürdürülebilir turizmin sosyal boyutuyla ele almak için öncelikle sürdürülebilir turizmin önemli bir prensibi olan işletmenin yerel kültürü koruma, gelecek nesillere aktarma hususunda ne gibi işlevleri olabilir diye sorulduğunda katılımcı bu durumu aşağıdaki gibi belirtmiştir.

"Burası çok ciddi bir define bölgesi. Eski Ipek Yolu'nun geçiş bölgesi çünkü. En büyük misyonumuz burada yapılan kazıları ve kaçakçılıkları ihbar etmek oluyor bu konuda. Yerel halkı koruyup bilinçlendirme amacımız var. Kendi bünyemizde çalışan 20 personel ve bunların aileleri ile beraber ciddi farkındalık yarattılar. Onun dışında Kandıra'nın sahip çıkmadığı Kandıra Bezi'ne Kandıra Hindisi'ne biz daha çok sahip çıkıyoruz. Bunu tanıtımlarda kullanıyoruz. Nar Anne'nin çok ciddi koleksiyonları var bu konuda. Yüzlerce özel Kandıra Örtüsü var."

Sosyal boyutla ilgili olarak araştırılan bir başka soru ise, çalışanlara çevresel faaliyetler hakkında eğitimler verilip verilmediği idi. Yapılan gözlemler sonucunda çalışanların bu konuda bilinçli oldukları ve bu konuya otel yönetiminin de çok önem verdiği görülmüştür. Bu soruyu katılımcı şu şekilde yanıtlamıştır. 
"Yakın zamanda iş sağlığı ve güvenliği eğitimi aldılar. Ondan evvel çevreye duyarlılık ve çevre bilinci konusunda eğitim verildi hepsine. Hepsinin sertifikaları var ellerinde. Zaten kendi içimizde de eğitimimiz her gün devam ediyor."

Sosyal boyutla ilgili olarak son olarak ele alınan konu ise, gelen misafirlere bölge, kültür, ekolojik hayat ve faaliyetler hakkında bilgiler verilip verilmediği idi. Bu konuyu katıımcı aşağıdaki gibi anlatmıştır.

"Bu yaptığımız sohbeti ben her misafirle yapıyorum. Ben yetişemezsem Nar Anne burada oluyor, eşi burada oluyor, eşim, onların kızı, her birimiz bu bilgilere sahibiz. Hepimiz zaten bu iletişimi misafirle kurabiliyoruz. Ufak otel olmanın faydaları bu. En kalabalık 50 kişi oluyor. Çocuğunu ekim dikime götürüyor, çocuk toprağa değiyor, çocuğuna süt sağdırıyor, kendi de sağıyor. Sağdığı sütü çocuğa kaynatıp kahvaltıda veriyoruz, peynir yaptırıyoruz, kendi yaptığı peyniri yiyor, Öğlenleyin de peynir alt suyundan çorbasını içiyor."

\section{Resim 3: Ekim dikim faaliyetine katılan bir çocuk}

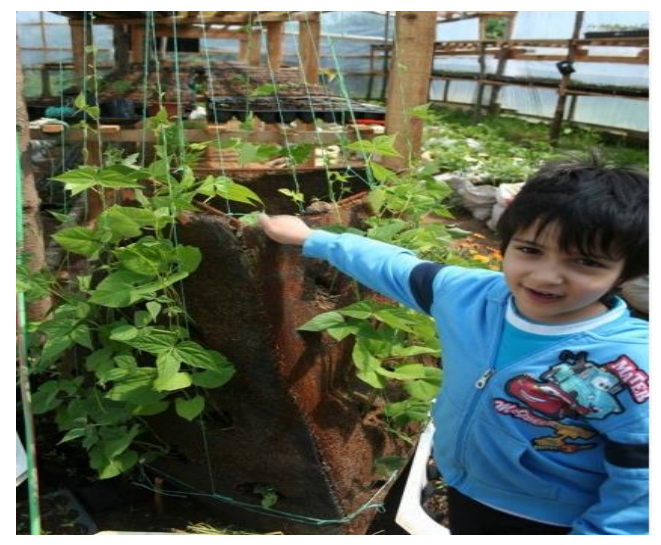

Yukarıda belirtilen bilgiler ve gözlemler sonucunda ekolojik otelin sosyal faaliyetlerinin sürdürülebilir turizmin olumsuz çevresel ve sosyo-kültürel etkilerin minimuma indirgenmesi için aktivitelerini hem turistler hem de yerel halkın sorumluluğunda düzenlemesi, ziyaretçiler için yüksek kalitede bir deneyim sağlamak, çalışanları ve misafirleri sürdürülebilirlik hakkında eğitmek gibi önemli hususları ile uyum içerisinde olduğu gözlemlenmektedir.

\section{Sonuç ve Öneriler}

Iwanovski ve Rushmore (1994) yapmış oldukları çalışmada çevre dostu otellerin özelliklerinden birkaçını katı-atık yönetimi, tek kullanımlık yerine tekrar kullanılabilir ürünler içeren, kimyasal kullanımını minimize eden, ürün ömrünü uzatma odaklı, mümkün olduğunca geri dönüşüm uygulayan, suyu koruma odaklı çalışan, enerji tasarrufu yönetimini iyi yapan, ekipman verimliliğini artırmaya yönelik koruyucu bakım programlarına sahip, yeşil etikete sahip olmak olarak sıralamışlardır. Bu özelliklerin yanında sosyal ve ekonomik özellikleri ile de ekolojik otellerin sürdürülebilir turizmin temel prensiplerini detaylı bir şekilde barındırdığı ve sürdürülebilir turizmin belki de en iyi örneklerinden biri olduğu söylenebilir. Araştırmadan elde edilen veriler de ekolojik otel faaliyetlerinin sürdürülebilir turizmin bütün amaçları ve prensipleri ile örtüştüğünü göstermektedir. Buna göre Narköy Ekolojik Oteli örnek uygulamaları göz önüne alınarak destinasyonların özelliklerine uygun ekolojik oteller oluşturulması ile doğa ve 
çevre dostu turizm ürünlerinin artırılması sürdürülebilir otel işletmeleri ve destinasyonlar yaratılmasına katkı sağlanacaktır. Ekolojik otel işletmelerinin sayısının artması ise başta otel sahipleri ve yöneticileri başta olmak üzere tüm paydaşların çevresel duyarlılığı ve sürdürülebilirlik ilkelerini ön planda tutmasına bağlıdır. Ancak merkezi yönetim ve destinasyon yönetiminden sorumlu otoritelerin çıkardıkları yasal düzenlemeler ile bu sürece müdahil olması ve gerekli desteği vererek kolaylaştırıcı bir rol üstlenmesi konusu göz ardı edilmemelidir.

Turizm daha çok özel sektör ağırlıklı bir sektördür ve bu özelliği sebebiyle turizmde öncelik yüksek kar elde etmek olmuştur. Bunun bir sonucu olarak da çevresel faktörler başlangıçta göz ardı edilmiş ve sürdürülebilirlik konusunda geç hareket edilmeye başlanmıştır. Kontrol edilmesi güç bir sektör olan turizmde denetim ve teşvik yoluyla yatırımcının; eğitim ve kullanılan teknolojiler yoluyla da tüketicinin çevreye olan zararlı etkileri azaltılmalıdır. Turizm işletmelerinin çevreye duyarı binalar inşa etmeleri, teknik bilgi ve finansal destek sağlanarak özendirilmelidir. Bir turizm faaliyeti iyi yönetilmediği takdirde çevre için geri dönüşü olmayan sorunlara sebep olurken, aynı faaliyet iyi yönetilerek çevreye katkı sağlayabilmektedir (Seyhan ve Yılmaz, 2010). Bu bağlamda bunun iyi örneklerini oluşturan ve gün geçtikçe önemi artan yeşil oteller ve özellikle ekolojik otellerin sayıca artması ve bu sayede işletmecilerin ve toplumun bilincinin de üst seviyeye çıkarılması için otoriteler tarafından çaba harcanması ve farkındalık yaratılması önerilmektedir.

Özellikle örnek olarak incelenen Narköy'ün varlığının bölgenin sürdürülebilirliği adına önemli bir yeri olduğu gözlemlenmiştir. Yapılan faaliyetler, gelişmekte olan ve sanayileşme riski çok yüksek olan Kandıra bölgesi için hayati önem taşımaktadır. Narköy sürdürülebilir uygulamaları sayesinde bölgelerarası dengesizliklerin azaltılmasına, yerel halkın çevreyi koruma ve geliştirme bilincinin artmasına, yörenin doğal ve kültürel zenginliklerinin tanıtım ve korunmasına, turizm sektörünün en büyük sorunu olan mevsimselliğin azaltılmasına katkıda bulunmaktadır. Bunun sonucunda ekolojik otellerin diğer alternatif turizm çeşitleri ile bir araya getirilen yeni ürün oluşturma çabaları sayesinde hem müşteri memnuniyetinin artması hem de sektörün beklentilerine cevap vermesi açısından ele alınması ve örnek olarak gösterilmesi önerilmektedir. Örneğin, tarım ve hayvancılığın odak işi olduğu çiftliklerin ekolojik otellere dönüştürülmesi hem turizm sektöründe aranılan alternatif turizm çeşidini oluşturacak hem de tarım sektörü için ekonomik katkı sağlayacak adımların atılmasına vesile olacaktır.

Sonuç olarak, Narköy'den yola çıkıp ifade etmek gerekirse, ekolojik oteller sürdürülebilir turizm için hayati öneme sahiptir. Sürdürülebilir turizmin gelişmesi, tüm kesimlerce anlaşılması, devamlılık arz edebilmesi adına çok önemli işlevleri bulunmaktadır. Bu bakımından ekolojik oteller sürdürülebilirlik kapsamında önemli bir yer işgal etmektedir. Ekolojik otel farkındalığını ölçmek için yerel halkın bakış açısını belirten nicel bir araştırma yapılması da bu konuda araştırma yapmak isteyen araştırmacılara önerilebilir. Ayrıca ekolojik olma konusunda adım atmayan otel işletmeleri ile ekolojik otel işletmelerinin çevre ile ilgili uygulamaları, rekabet ve kar elde etme durumları, müşteri memnuniyeti, pazarlama ve tanıtım stratejileri vb. konular açısından karşılaştırıldıkları araştırmalar ekolojik otellerin daha iyi anlaşılmasına katkı sağlayacaktır.

\section{Kaynakça}

Akşit, S (2007), Doğal Ortam Duyarlıı̆̆ı Açısından Sürdürülebilir Turizm, Erciyes Üniversitesi Sosyal Bilimler Enstitüsü Dergisi, 23(2), ss.441-460. 
Avcıkurt, C (1997), Avrupa Birliği ile Bütünleşme Sürecinde Türk Turizmi Sorunlar ve Çözüm Önerileri, Doktora Tezi, Balıkesir Üniversitesi Sosyal Bilimler Enstitüsü, Balıkesir

Başgöze, P. ve N. A. Bayar (2015), Eko Otellerden Hizmet Satın Alımında Kuşaklar Arası Farklılaşmalar Üzerine Bir Çalışma, Sosyoekonomi Dergisi, 23(24), ss. 118-130.

Beyhan, Ş. G. ve S. M. Ünügür (2005). Çağdaş Gereksinimler Bağlamında Sürdürülebilir Turizm ve Kimlik Modeli, I.T.Ü. Mimarlık, Planlama, Tasarım Dergisi,. 4(2), ss. 79-87.

Borsa İstanbul (2014), Şirketler İçin Sürdürülebilirlik Rehberi, www.borsaistanbul.com, (19.07.2016).

Ceylan, T. (2001), Turizm ve Sürdürülebilir Gelişme, Anatolia: Turizm Araştırmaları Dergisi, 12(2), ss.169-177.

Cooper, I. (1998). Emerging Issues in Environmental Management A.K. (Ed.) içinde: Facility Management: Theory and Practice London: Spon Press.

Cooper, C. ve S. Wahab (2001). Tourism's Approach to Sustainability / Conclusion, Ed. Salah Wahab ve Chris Cooper, Tourism in the Age of Globalisation, London: Routledge.

Dief, M. E. ve X. Font (2010), The Determinants of Hotels' Marketing Managers Green Marketing Behaviour, Journal Of Sustainable Tourism, 18(2), ss.157-174.

Erdoğan, N. (2003), Çevre ve Ekoturizm, Erk Yayınları: Ankara.

Garrod, B. ve A. Fyall (1998). Beyond The Rhetoric of Sustainable Tourism?, Tourism Management, 19(3) .ss.199-212.

Güneş, G. (2011), Konaklama Sektöründe Çevre Dostu Yönetimin Önemi, KMÜ Sosyal ve Ekonomik Araştırmalar Dergisi, 13(20), ss. 45-51.

Han, H, L.-T.J. Hsu, J.-S. Lee, C. Sheu (2011), Are Lodging Customers Ready To Green? An Examination of Attitudes, Demographics, and Eco-Friendly Intentions, International Journal of Hospitality Management, 30(2), ss.345-355.

Iwanowski, K. ve C. Rushmore, (1994). Introducing the eco-friendly hotel. The Cornell Hotel and Restaurant Administration Quarterly, 35(1), ss.34-38.

İslamoğlu, H. ve Alnıaçık, Ü.(2013) Sosyal Bilimlerde Araştırma Yöntemleri, Beta Yayınevi: İstanbul

Lim, C. ve McAleer, M. (2005), Ecologically sustainable tourism management, Environmental Modelling \& Software, 20(11), ss. 1431-1438.

Manaktola, K. ve Jauhari, V. (2007). Exploring consumer attitude and behaviour towards green practices in the lodging industry in India, International Journal of Contemporary Hospitality Management, 19(5), ss.364-377.

Miles, M. ve Huberman, A. B. (1995) Qualitative Data Analysis, Sage Publication: London.

Özkan, Y. E. (2005), Turizmin geleceği: ekoturizm, Standard Dergisi, 42(500).

Öztürk, S. (2005), Kastamonu-Bartın Küre Dağları Milli Parkı'nın Rekreasyonel Kaynak Değerlerinin İrdelenmesi, Süleyman Demirel Üniversitesi Orman Fakültesi Dergisi, A(2), ss. 138-148.

Pehlivanoğlu, B. (2010), Hip Otel (Highly Individual Places/ Kendine Özgü Mekanlar) Olarak Tanımlanan Konaklama Mekanlarının Kavramsal, Estetik ve İşlevsel Analizi, Sanatta Yeterlik Tezi, Mimar Sinan Güzel Sanatlar Üniversitesi Fen Bilimleri Enstitüsü, İstanbul.

Punch, K.F. (2005), Sosyal Araştırmalara Giriş, Nicel ve Nitel Yaklaşımlar. (Çeviri: Zeliha Etöz). Siyasal Kitabevi Yayınları: Ankara.

Seyhan, G. ve B. S. Yılmaz (2010), Sürdürülebilir Turizm Kapsamında Konaklama İşletmelerinde Yeşil Pazarlama: Calista Luxury Resort Hotel, Dokuz Eylül Üniversitesi Iş̧letme Fakültesi Dergisi, 11(1), ss. 51-74.

The Nature Conservancy. About Art Travel, www.nature.org (30.12.2015). 
Turizm Dosyası (2016), Yeşil Yıldızlı Otel Sayısı 327 Oldu, www.turizmdosyasi.com (19.07.2016).

UNWTO 2009. WTO-UNEP concept paper. International year of ecotourism 2002, http://sdt.unwto.org/ (22.12.2015).

Yıldırım, A. ve H. Şimşek (2006), Sosyal Bilimlerde Nitel Araştırma Yöntemleri, 6. Baskı, Seçkin Yayınevi: Ankara.

Yıldırım, A. ve Şimşek, H. (2013), Sosyal Bilimlerde Nitel Araştırma Yöntemleri, 9. Baskı, Seçkin Yayınevi: Ankara.

Yin, R. K. (2011), Qualitative Research from Start to Finish, The Guilford Press: London. 